\title{
Defective regulation of phosphatidylinositol-3-kinase gene expression in skeletal muscle and adipose tissue of non-insulin-dependent diabetes mellitus patients
}

\author{
F. Andreelli, M. Laville, P.-H. Ducluzeau, N. Vega, P. Vallier, Y. Khalfallah, J.-P. Riou, H. Vidal \\ INSERM U.449 and Centre de Recherche en Nutrition Humaine de Lyon, Faculté de Médecine R. T.H. Laënnec, and Service \\ d'Endocrinologie Diabétologie et Nutrition, Hopital E. Herriot, Lyon, France
}

\begin{abstract}
Summary We investigated the regulation of the mRNA expression of the insulin receptor, insulin receptor substrate-1 (IRS-1) and p85a-phosphatidylinositol-3-kinase (PI-3K), three major actors of insulin action, in skeletal muscle from 10 healthy lean volunteers, 13 obese patients with Type II (non-insulindependent) diabetes mellitus and 7 non-diabetic obese subjects. The in vivo regulation by insulin was studied using a 3-h euglycaemic, hyperinsulinaemic clamp. There were no differences in the basal concentrations of the three mRNAs in skeletal muscle between groups. Insulin infusion produced a twofold reduction in insulin receptor substrate- 1 mRNA expression in the three groups $(p<0.02)$. In contrast, insulin increased p $85 \alpha$-phosphatidylinositol-3-kinase mRNA expression in muscle from non-diabetic subjects $(+98 \pm 22 \%$ in lean and $+127 \pm 16 \%$ in obese, $p<0.02)$ but this effect was totally impaired in Type II diabetic patients $(+5 \pm 12 \%$, NS $)$. A similar defect
\end{abstract}

in insulin action on p85 $\alpha$-phosphatidylinositol-3-kinase mRNA expression was observed in abdominal subcutaneous adipose tissue $(+138 \pm 25 \%, p<0.01$ in lean and $+46 \pm 14 \%, p<0.02$ in obese and $+29 \pm 11 \%$, NS in Type II diabetic patients). The lack of action of insulin on p85 $\alpha$-phosphatidylinositol-3-kinase mRNA in diabetic subjects was probably not due to a deleterious effect of hyperglycaemia since improvement of the glycaemic control for 10 days did not restore the response in muscle or in adipose tissue. This study provides evidence for a defect in the regulation by insulin of PI-3K gene expression in Type II diabetic patients, thus reinforcing the concept that alterations at the gene expression might be involved in the pathogeny of Type II diabetes. [Diabetologia (1999) 42: 358-364]

Keywords Hyperinsulinaemic clamp, insulin receptor, IRS-1, RT-PCR.
Despite intensive efforts, the nature of the molecular defects leading to the development of Type II (noninsulin-dependent) diabetes mellitus is poorly understood. Whereas both alterations in insulin secretion and action are involved in established diabetes $[1,2]$, it has been suggested that defects in insulin action

Received: 26 August 1998 and in revised form: 23 October 1998

Corresponding author: Dr. H. Vidal, INSERM U.449, Faculté de Médecine R. T.H. Laënnec, Rue G. Paradin, F-69373 Lyon Cédex 08, France

Abbreviations: IRS-1, Insulin receptor substrate-1; PI-3K, p85 $\alpha$ regulatory subunit of phosphatidylinositol 3-kinase; RTPCR, reverse transcription polymerase chain reaction. precede the onset of the disease [3]. There is good evidence that insulin resistance in Type II diabetes is dependent, at least in part, on genetic factors $[4,5]$. The mutations identified so far in the sequences of candidate genes can, however, explain only a small proportion of the different forms of Type II diabetes [5]. Changes in biological functions in response to environmental factors are also involved in the development of the disease [4]. The modulation of the expression of specific key genes is one of the main mechanisms for changing biological function in response to the environment. Several lines of evidence indicate that the expression of some important genes in insulin action is abnormal in peripheral tissues in the common form of Type II diabetes. For example, the basal concentration of the insulin sensitive glu- 
cose transporter (Glut 4) is reduced in adipose tissue [6], whereas the mRNA expression of the glycogen synthase [7] or hexokinase II [8] is altered in skeletal muscle of insulin-resistant diabetic patients. These changes could be an adaptation of gene expression, secondary to the disease [8]. Alternatively, they could reflect an initial alteration in the machinery that regulates gene expression. Defects in nuclear regulatory proteins of the insulin receptor gene have been found in two patients with Type II diabetes [9], and mutations in trans-acting factors have been involved in the pathogeny of subtypes of maturity-onset diabetes of the young $[10,11]$. If defective trans-acting factors are also present in the main forms of Type II diabetes, altered regulation of the expression of specific genes might be expected.

Several studies have identified defects in the first events of the insulin signalling cascade in skeletal muscle of patients with Type II diabetes. Phosphorylations of the insulin receptor and insulin receptor substrate-1 (IRS-1) in response to insulin have been found impaired in diabetic muscle [12-14]. The induction of phosphatidylinositol 3-kinase activity by insulin is also greatly reduced in Type II diabetic patients $[13,14]$. These alterations affect, however, the rapid post-translational regulation of the proteins and little is known regarding possible defects in the regulation of the expression of the genes encoding the components of the insulin signalling pathways. The protein concentrations of the $p 85 \alpha$ regulatory subunit of phosphatidylinositol 3-kinase (PI-3K) have been found to be decreased in skeletal muscle of insulin resistant obese patients [15] and, in adipose tissue, the concentration of IRS-1 protein is reduced by $70 \%$ in Type II diabetes [16]. The regulation of the gene expression of these fundamental actors of insulin action has never been reported in tissues of insulin resistant patients.

We have recently shown that insulin rapidly upregulates PI-3K mRNA expression in muscle of young healthy lean subjects [17]. The aim of this study was to investigate the regulation by insulin of the expression of the genes encoding insulin receptor, IRS-1 and PI-3K in skeletal muscle of Type II diabetic patients. The mRNA of these target genes was quantified by reverse transcription-competitive polymerase chain reaction (RT-competitive PCR) [17, 18]. A group of non-diabetic obese subjects, matched for age and body mass index (BMI) with the Type II diabetic patients, was also studied as a control for obesity-related insulin resistance. In order to assess a possible deleterious effect of chronic hyperglycaemia on the regulation by insulin of gene expression in Type II diabetes, glycaemic control was improved in a subgroup of diabetic patients by 10 days of continuous insulin therapy.

\section{Subjects and methods}

Subjects. Ten healthy lean volunteers (seven women and three men, age $=51 \pm 2$ years, BMI $\left.=23 \pm 1 \mathrm{~kg} / \mathrm{m}^{2}\right)$, seven non-diabetic obese subjects (five women and two men, age $=41 \pm 4$ years, BMI $\left.=35 \pm 1 \mathrm{~kg} / \mathrm{m}^{2}\right)$ and 13 obese patients with Type II diabetes (eight women and five men, age $=53 \pm 2$ years, $\mathrm{BMI}=31 \pm 1 \mathrm{~kg} / \mathrm{m}^{2}, \mathrm{HbA}_{1 \mathrm{c}}=10.7 \pm 0.7 \%$, duration of diabetes $=7.1 \pm 1.2$ years) participated in the study. None of the control subjects had a family or personal history of diabetes, obesity, dyslipidaemia or hypertension. The diabetic patients interrupted, under medical control, their usual treatment (oral antidiabetic agents) at least 1 week before admission. None of the obese subjects had impaired glucose tolerance as assessed by the classical oral glucose tolerance test. All participants gave their written consent after being informed of the nature, purpose and possible risks of the study. The experimental protocol was approved by the ethics committees of the Hospices Civils de Lyon and was carried out according to French legislation (Huriet law).

Study design. All studies were done on subjects who were in the postabsorptive state, after an overnight fast. To investigate insulin action on glucose metabolism and on target gene expression, the subjects were submitted to a 3-h euglycaemic, hyperinsulinaemic clamp [19]. To verify whether hyperglycaemia exerts an adverse effect on insulin action, 6 patients with Type II diabetes were investigated before and after 10 days of insulin treatment by continuous insulin infusion to reduce fasting glycaemia to normal concentrations.

Euglycaemic hyperinsulinaemic clamp. The basal glucose turnover rate was determined by tracer dilution methodology with a primed $\left[6,6-{ }^{2} \mathrm{H} 2\right]$ glucose (Eurisotop, St Aubain, France) infusion $(0.11 \mu \mathrm{mol} / \mathrm{kg}$ per min $)$ for $3 \mathrm{~h}$ as described previously $[17,20]$. Then a 3-h euglycaemic, hyperinsulinaemic clamp was started by the infusion of insulin (Actrapid Novo, Copenhagen, Denmark) at a rate of $450 \mathrm{pmol} / \mathrm{m}^{2}$ per min $[17,20]$. Primed $\left[6,6-{ }^{2} \mathrm{H} 2\right]$ glucose was infused $(0.55 \mu \mathrm{mol} / \mathrm{kg}$ per min $)$ during the clamp to determine glucose turn-over rate and any decrease in blood glucose was prevented by adapted infusion of $20 \%$ glucose solution (Aguettant, Lyon, France). For the determination of metabolites, hormones and $\left[6,6-{ }^{2} \mathrm{H} 2\right]$ glucose isotopic enrichment, blood samples were drawn every $10 \mathrm{~min}$ both during the last $30 \mathrm{~min}$ of the basal period and the last hour of the hyperinsulinaemic clamp. Metabolite and hormone concentrations were measured using enzymatic methods and radioimmunoassays. Plasma isotopic enrichment of $\left[6,6{ }^{2} \mathrm{H} 2\right]$ glucose was determined by Gas-Chromatography-Mass Spectrometry (5971 MSD, Hewlett-Packard, Palo Alto, Calif., USA) as described [20]. Glucose turn-over rates were calculated during the basal state and the last hour of the hyperinsulinaemic clamp using steady-state equations. For Type II diabetic patients, glucosuria was substracted from glucose turn-over rates to calculate glucose uptake. To estimate glucose and lipid oxidation rates, respiratory exchange measurements were taken during the final $30 \mathrm{~min}$ of both the basal and the clamp periods with a flow-through canopy gas-analyser system (Deltatrac Metabolic Monitor, Datex, Helsinki, Finland) [20].

Intensive insulin therapy. Six of the diabetic patients (three women and three men, age $=56 \pm 2$ years, fasting glycae$\mathrm{mia}=13.1 \pm 1.4 \mathrm{mmol} / \mathrm{l}, \quad$ fasting insulinaemia $=55.3 \pm 10.3$ $\mathrm{pmol} / \mathrm{l}, \mathrm{BMI}=31 \pm 2 \mathrm{~kg} / \mathrm{m}^{2}, \mathrm{HbA}_{1 \mathrm{c}}=10.9 \pm 0.5 \%$ ) were treated for 10 days by continuous subcutaneous insulin infusion to lower glycaemia. Insulin infusion rates were adapted according 
to the glycaemia concentrations that were checked eight times a day. Insulin boluses were given before each meal and adapted to carbohydrate intake as described [21]. The short-term effects of insulin on gene expression were investigated by hyperinsulinaemic clamp before therapy and the morning after the 10 days of treatment. When the second clamp study was started, mean fasting glycaemia was $7.0 \pm 0.8 \mathrm{mmol} / \mathrm{l}$ and mean fasting insulinaemia was $62 \pm 30 \mathrm{pmol} / \mathrm{l}$ in the six treated patients.

Muscle and adipose tissue biopsies. Muscle and adipose tissue biopsies were taken under local anaesthesia (2\% Lidocaine), at the beginning of the basal period and end of the hyperinsulinaemic clamp period, as described previously [17, 22]. Briefly, muscle samples were obtained by percutaneous biopsies of the vastus lateralis muscle using Weil Blakesley pliers $(57 \pm 4 \mathrm{mg}$ wet wt, $n=71$, no difference in size between samples from control, obese and Type II diabetic subjects or before and after clamp). Abdominal subcutaneous adipose tissue was aspirated from the periumbilical area through a 15-gauge needle $(265 \pm 30 \mathrm{mg}$ wet wt of tissue were used for total RNA preparation, $n=58$, no difference in average size between groups or before and after clamp). Tissue samples were immediately frozen in liquid nitrogen and stored at $-80^{\circ} \mathrm{C}$ for further analysis.

Total RNA preparation. Tissue samples were pulverised in liquid nitrogen and total RNA was prepared according to with slight [23] modifications for muscle samples and using the RNeasy total RNA kit from Qiagen (Courtaboeuf, France) for adipose tissue [22]. In addition to absorbance measurements, concentration and integrity of the RNA preparations were carefully verified in agarose gels stained with ethidium bromide. Average yields of total RNA were $28 \pm 2 \mu \mathrm{g} / 100 \mathrm{mg}$ of muscle (wet wt) and $1.1 \pm 0.2 \mu \mathrm{g} / 100 \mathrm{mg}$ of adipose tissue (wet wt) and were not different in tissues from control, obese and Type II diabetic subjects, before or after the clamp. Total RNA solutions were stored at $-80^{\circ} \mathrm{C}$ until quantification of the target mRNAs.

Quantification of messenger RNAs. The concentration of the mRNAs encoding insulin receptor (total and exon 11 forms), IRS-1 and PI-3K was measured by RT-competitive PCR [17, 18]. The method relies on the addition of a known amount of a competitor DNA molecule in the PCR to standardize the amplification process $[18,24]$. The construction of the competitors, the validation of the assays and the conditions of the RTPCR reactions have been described previously $[17,18]$. The RT-PCR assay made possible the quantification of the insulin receptor mRNA variant containing the exon 11 (with sense PCR primer specific for exon 11) and total insulin receptor mRNAs (with sense PCR primer specific for exon 12 which is a common exon for the forms with and without exon 11) [17]. For each mRNA, the specific first strand cDNA was synthetized from $0.1 \mu \mathrm{g}$ of total RNA. During the PCR, we used sense primers that were $5^{\prime}$-end labelled with $\mathrm{Cy}-5$ fluorescent dye (Eurogentec, Seraing, Belgium). Their sequences were identical to those reported previously [17]. The use of these primers allowed the synthesis of fluorescent PCR products that were analysed with an automated laser fluorescence DNA sequencer (ALFexpress, Pharmacia, Upsala, Sweden) in $4 \%$ denaturating polyacrylamide gels. The initial concentration of target mRNA was determined at the competition equivalence point as described [18]. Control experiments were routinely carried out to verify the absence of PCR contamination or genomic DNA amplification.

Presentation of the results. The RT-competitive PCR assay used in this study made it possible to determine the absolute amounts of target mRNAs [18]. Moreover, total RNAs were prepared using standardized methods and their concentrations were carefully verified. Therefore, the results are presented as absolute concentrations, in amol/ $\mu \mathrm{g}$ of total RNA. To accurately determine the effect of insulin, total RNA of the two muscle (or adipose tissue) biopsies from the same person (before and after clamp) were prepared simultaneously and the assays of the target mRNAs were always made in the same run of PCR, with the same working solutions of competitor. The data presented in this work generally corresponded to the single determination of a target mRNA in a given biopsy. The coefficiant of variation of the RT-competitive PCR method is less than $10 \%$ [18].

The data are presented as means \pm SEM. Statistical significance of the results was determined using Kruskal-Wallis and Mann-Whitney nonparametric tests when comparing obese, Type II diabetic and control subjects. Wilcoxon nonparametric test for paired values was used when comparing mRNA concentrations before and after clamp in the same group of subjects. The threshold for significance was set at $p=0.05$.

\section{Results}

\section{Comparison of insulin-resistant patients and control subjects}

Hormonal and metabolic variables. After an overnight fast, insulin, non-esterified fatty acid and triglyceride concentrations were higher in obese and diabetic patients than in lean subjects. Diabetic patients had higher glycaemia and basal glucose uptake rates than control and obese subjects (Table). Basal glucose oxidation was not different in the three groups but basal lipid oxidation was increased in Type II diabetic and obese groups. During the hyperinsulinaemic clamp, the stimulation by insulin of glucose uptake rates were profoundly reduced ( $>50 \%$ vs lean subjects) in obese and Type II diabetic patients. Insulin-stimulated non-oxidative glucose disposal rates were decreased in these two groups whereas insulin-stimulated glucose oxidation was reduced in Type II diabetic patients only. During the clamp, non-esterified fatty acid concentrations and lipid oxidation remained higher in obese and Type II diabetic patients than in control lean subjects.

Insulin receptor, IRS-1 and PI-3K $m R N A$ expression. The concentrations of the transcripts, determined by RT-competitive PCR in total RNA preparations from vastus lateralis muscle, are presented in Figure 1. In the basal state, after an overnight fast, the mRNA levels of the three genes were not significantly different between subjects. Concentrations of PI$3 \mathrm{~K}$ mRNA tended to be decreased in muscle of obese subjects but the difference was not significant due to large individual variations (values ranging from 5 to $36 \mathrm{amol} / \mu \mathrm{g}$, see also Fig. 2). For the insulin receptor, the percentage of the isoform with exon 11 was not significantly different in muscle from the three 
Table 1. Clinical and metabolic characteristics of the subjects before and during euglycaemic, hyperinsulinaemic clamp. Metabolic variables were determined during the last $30 \mathrm{~min}$ of the basal period and during the last hour of the clamp (see text for details). Non oxidative glucose disposal (NOGD) rates corresponded to the rate of insulin-stimulated glucose uptake minus the rate of insulinstimulated glucose oxidation during the last hour of the clamp. Data are means $\pm \mathrm{SEM},{ }^{\mathrm{a}} p<0.05$ and ${ }^{\mathrm{b}} p<0.01$ compared with the data of the healthy lean subjects (n.d. = not determined)

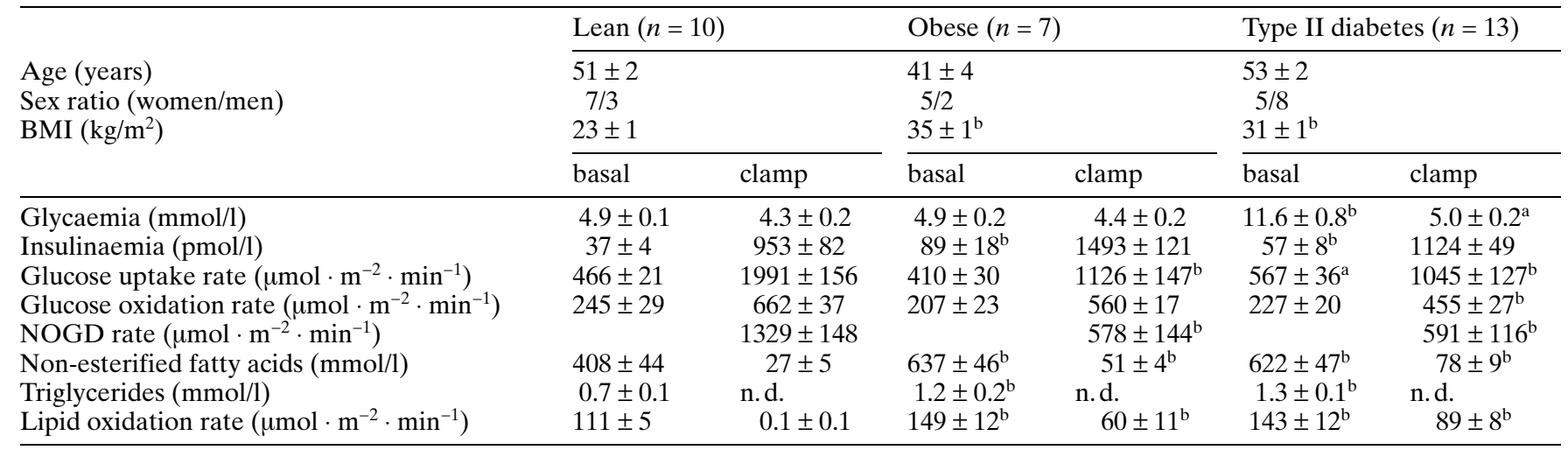

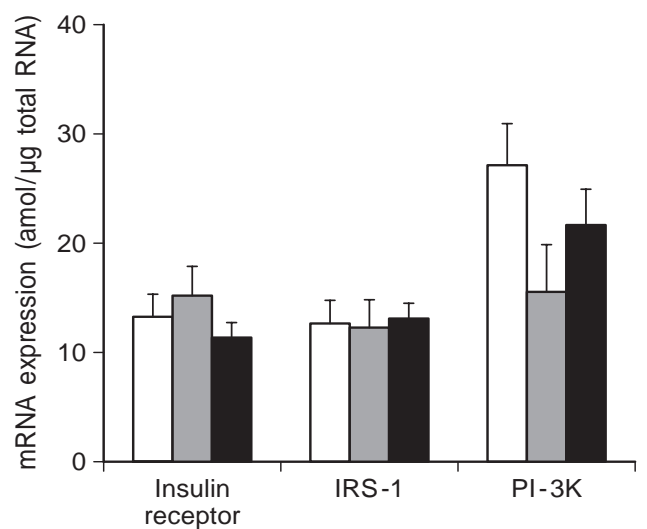

Fig.1. Comparison of the mRNA expression of insulin receptor, IRS-1 and p85 $\alpha$ subunit of phosphatidylinositol 3-kinase in skeletal muscle from lean, obese and Type II diabetic subjects. Specific mRNA expressions were quantified by RT-competitive PCR in total RNA preparations from vastus lateralis skeletal muscle biopsies from 10 lean, 7 obese and 13 Type II diabetic subjects. For insulin receptor, the amounts of total insulin receptor (with plus without exon 11) are presented, $\square$, lean; $\square$, obese; $\square$, Type II diabetes

groups of subjects $(50 \pm 8 \%, 38 \pm 6 \%$ and $31 \pm 6 \%$ of insulin receptor mRNA with exon 11 in lean, Type II diabetic and obese groups, respectively, NS).

\section{Effects of $3 \mathrm{~h}$ insulin infusion on target $m R N A$ expression}

Insulin infusion induced a robust increase in PI-3K mRNA in skeletal muscle from lean $(+98 \pm 22 \%$, $p=0.003)$ and obese $(+127 \pm 16 \%, p=0.014)$ subjects (Fig. 2). This effect was completely impaired in Type II diabetic patients $(+5 \pm 12 \%, p=0.164)$. In contrast, IRS-1 mRNA expression was reduced after $3 \mathrm{~h}$ of hyperinsulinaemia in the three groups of sub- jects $(-42 \pm 6 \% p=0.003,-35 \pm 8 \% p=0.015$ and $-25 \pm 8 \% p=0.017$ in lean, obese and Type II diabetic subjects, respectively). Regarding insulin receptor, insulin has no significant effect on the expression of the total mRNAs in any of the three groups (Fig.2). In addition, the relative expression of the two isoforms of receptor was not affected by insulin $(53 \pm 8 \%, 43 \pm 7 \%$ and $31 \pm 6 \%$ of exon 11 form after clamp in lean, obese and Type II diabetic subjects, respectively; NS when compared with the values measured before clamp).

We further investigated whether the defect in the response of PI-3K mRNA expression to insulin observed in skeletal muscle also exists in adipose tissue in Type II diabetes. Due to the very low yield in total RNA recovery with adipose tissue (about $1 \mu \mathrm{g}$ / $100 \mathrm{mg}$ of tissue), the effect of insulin on the other mRNAs of interest was not investigated in this study. In abdominal subcutaneous fat tissue, PI-3K mRNA was highly expressed (Fig. 2), without significant difference between groups (209 $\pm 31,188 \pm 39$ and $267 \pm 31 \mathrm{amol} / \mu \mathrm{g}$ total RNA in lean, obese and Type II diabetic subjects, respectively; NS). Similar to what was found in skeletal muscle, insulin greatly induced PI-3K mRNA expression in lean $(+134 \pm$ $25 \%, p=0.004)$ and in obese $(+46 \pm 14 \%, p=$ $0.009)$ subjects but not in adipose tissue from Type II diabetic patients $(+21 \pm 14 \%, p=0.062)$.

\section{Insulin action on PI-3K gene expression in Type II diabetic patients with improved glycaemic control}

To verify whether chronic hyperglycaemia exerts a deleterious effect on the action of insulin on PI-3K gene expression, six of the Type II diabetic patients were treated for 10 days by continuous subcutaneous insulin therapy. In addition to considerably lower 

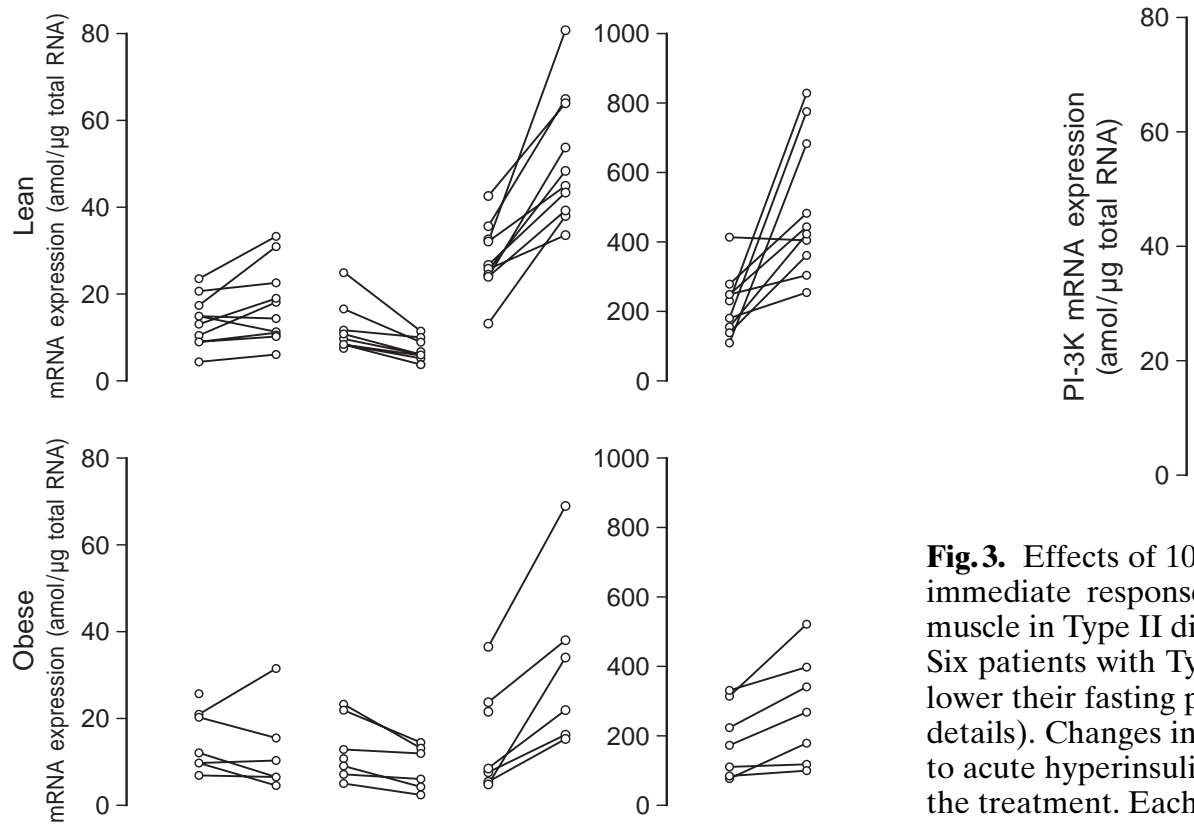
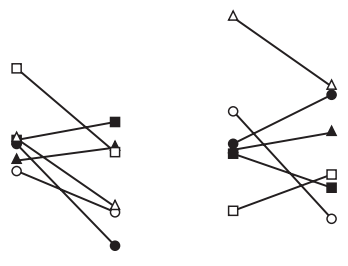

Before
treatment

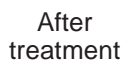

Fig. 3. Effects of 10 days of continuous insulin therapy on the immediate response of PI-3K mRNA to insulin in skeletal muscle in Type II diabetic patients.

Six patients with Type II diabetes were treated for 10 days to lower their fasting plasma glucose concentrations (see text for details). Changes in PI-3K mRNA concentrations in response to acute hyperinsulinaemia were investigated before and after the treatment. Each symbol represents a patient

vs before treatment, NS). The inhibition of lipid oxidation by insulin was more pronounced after treatment $\left(42 \pm 8\right.$ vs $81 \pm 9 \mu \mathrm{mol} \cdot \mathrm{m}^{-2} \cdot \mathrm{min}^{-1}$, after vs before treatment, $p=0.04$ )

Continuous treatment with insulin for 10 days did not affect the basal levels of PI-3K mRNA in skeletal muscle (33 \pm 2 and $31 \pm 5 \mathrm{amol} / \mu \mathrm{g}$ total RNA before and after treatment, respectively; NS). The rapid effect of insulin on PI-3K mRNA expression was not restored after therapy in skeletal muscle of the six Type II diabetic patients who received treatment (Fig. 3).

\section{Discussion}

In this work, we provide the first evidence that insulin-stimulated PI-3K gene expression is altered in skeletal muscle and in adipose tissue of Type II diabetic patients. Insulin resistance in Type II diabetes has been characterized by several defects in the first steps of the insulin signalling cascade. The rapid insulin-induced phosphorylations of insulin receptor and IRS-1 and the stimulation of phosphatidylinositol-3 kinase and Akt kinase activities have been reported to be reduced in Type II diabetes [12-15, 25]. All these events correspond to short-term post-translational regulation of protein functions. In addition to this level of regulation, defective regulation of the expression of genes encoding the key proteins of insulin action has been envisaged in Type II diabetes [26]. This hypothesis is supported by findings of altered expression of genes encoding metabolic enzymes in peripheral tissues of patients with Type II diabetes

[6-8] and by the recent discovery of mutations in

tive glucose disposal) did not, however, reach significance $\left(499 \pm 124\right.$ vs $352 \pm 117 \mu \mathrm{mol} \cdot \mathrm{m}^{-2} \cdot \mathrm{min}^{-1}$, after 
trans-acting factors in subtypes of diabetes [9-11]. Our aim was to verify whether the regulation of key genes of insulin action is altered in skeletal muscle of Type II diabetic patients. To do so, we investigated the in vivo regulation by insulin of the mRNA expression of insulin receptor, IRS-1 and PI-3K in muscle of healthy lean, Type II diabetic and non-diabetic obese subjects. The mRNA expression of these major actors of the insulin signalling cascade were quantified using the well accepted and recognized RT-competitive PCR based assay [24]. We have carefully validated this assay and shown that it determines, with accuracy and precision, the absolute amount of a given mRNA in a total RNA preparation from small tissue biopsies [18].

In the basal state, after an overnight fast, there was no significant difference in the expression of the mRNAs encoding insulin receptor, IRS-1 and PI-3K in the skeletal muscle of lean, Type II diabetic or non-diabetic obese subjects. In agreement with previous reports [27], we found that the relative expression of the two insulin receptor mRNA variants is not altered in muscle of Type II diabetic patients or obese subjects. Regarding PI-3K, most of the obese subjects have reduced mRNA expression but the difference from the lean control subjects did not reach significance. This tendency was, however, in agreement with the observed reduction of the PI$3 \mathrm{~K}$ protein concentration in skeletal muscle of obese subjects [15].

The action of insulin on metabolic pathways involves rapid modifications of the activity of the key controlling enzymes or changes in their expression levels or both [26]. Recently, we have shown that insulin induced PI-3K mRNA expression in human skeletal muscle [17]. Here we confirmed and extended this finding by showing that insulin increased, by more than twofold, the mRNA expression of PI-3K in muscle of healthy lean and obese subjects. This effect was completely impaired in patients with Type II diabetes. Similar results were found in subcutaneous adipose tissue, another tissue where phosphatidylinositol-3 kinase plays a crucial part in the signalling cascade of insulin [28]. This severe defect in the regulation of PI-3K mRNA expression in Type II diabetes is probably not the consequence of chronic hyperglycaemia, since lowering fasting plasma glucose concentrations and improving glycaemic control for several days of a subgroup of diabetics subjects did not restore the response to insulin.

The lack of action of insulin on PI-3K mRNA expression in Type II diabetic tissues might be related to the known defects in the insulin signalling cascade [12-15, 25]. However, PI-3K mRNA was induced by insulin in the tissues of non-diabetic, obese subjects who were also characterized by a pronounced state of insulin resistance of whole body glucose disposal. Thus, these results suggest that distinct insulin signal- ling pathways could occur for the control of glucose metabolism and for the control of PI-3K expression. Alternatively, they argue for a specific defect in the control of gene expression in Type II diabetes, independent of obesity and insulin resistance of glucose disposal. Altered regulation by insulin of other genes, like those encoding glucose transporter 4(Glut 4) [29] or hexokinase II [8], have been observed already in skeletal muscle of patients with Type II diabetes. Taken together, these results suggest that the regulation of a network of genes involved in insulin action could be affected in Type II diabetes. If this hypothesis can be confirmed, identification of a common mechanism controlling the expression of these genes (like a common trans-acting factor) might certainly be of great importance for the understanding of the pathology. At that stage of the study, however, it could not be ruled out that the observed defective regulation of PI-3K mRNA expression was due to a mutation in the promoter region of the gene. The sequence of the human promoter of the p85 $\alpha$ subunit of phosphatidylinositol-3 kinase is not yet available. A recent genetic study did not, however, indicate an association between PI-3K gene polymorphism and insulin resistance in Type II diabetes [30].

Insulin infusion induced a significant reduction of IRS-1 mRNA in skeletal muscle in the three groups of subjects. This effect was not observed in our previous study in lean volunteers that were younger [17] than those in this work. In addition to the difference in age, large improvements in the methodology (separation of the PCR products in acrylamide instead of agarose gel electrophoresis and determination of the real concentrations instead of the relative abundances of $\beta$-microglobulin mRNA) might explain these discrepancies. Importantly, the effect of insulin on IRS-1 mRNA expression was not impaired in the muscle of Type II diabetic patients, in contrast to that found with PI-3K mRNA. This result suggests distinct mechanisms of action on the two mRNAs. It is also interesting to draw a parallel between the reduced expression of IRS- 1 mRNA during the hyperinsulinaemic clamp and the decrease in IRS-1 protein concentrations observed in cultured cells during prolonged incubation with insulin [31]. Taken together, these results indicate that insulin downregulates IRS-1 expression. In addition to the proposed mechanism of an insulin-induced proteolytic cleavage of IRS-1 protein [32], our results suggest that insulin could also reduce IRS-1 gene expression.

Total insulin receptor mRNAs and the relative abundance between the two receptor isoforms were not modified after $3 \mathrm{~h}$ of hyperinsulinaemia in human skeletal muscle. In cultured cells and in diabetic animals, it has been shown that insulin exerts a negative control on insulin receptor mRNA expression [33, 34]. This down-regulation probably did not occur dur- 
ing the short hyperinsulinaemia obtained during the clamp.

In summary, we show that insulin rapidly increases the mRNA levels of $\mathrm{p} 85 \alpha$ subunit of phosphatidylinositol-3 kinase in skeletal muscle and in adipose tissue in vivo in humans. Furthermore, we show that this effect is impaired in the tissues of diabetic patients, suggesting a defective regulation of PI-3K gene expression in Type II diabetes. Because PI-3K mRNA is normally induced in tissue from insulin resistant non-diabetic obese subjects, a distinct insulin signalling pathway could exist for the control of glucose metabolism and the control of gene expression. Alternatively, Type II diabetes might be associated to a specific defect in the signalling to the nucleus or in the transcriptional machinery.

Acknowledgements. The authors acknowledge C. Urbain, J. Peyrat and M. Odeon for excellent technical assistance.

This work was supported in part by grants from La Fondation de France and from A.L.F.E.D.I.A.M.-Novo Nordisk.

\section{References}

1. DeFronzo RA, Bonadonna RC, Ferrannini E (1992) Pathogenesis of NIDDM: a balanced overwiew. Diabetes care 15: 318-368

2. Yki-Järvinen H (1995) Role of insulin resistance in the pathogenesis of NIDDM. Diabetologia 38: 1378-1388

3. Martin BC, Warram JH, Krolewski AS, Bergman RN, Soeldner JS, Khan RC (1992) Role of glucose and insulin resistance in development of type-2 diabetes mellitus: results of a 25 -years follow-up study. Lancet 340: 925-929

4. Kahn RC (1994) Insulin action, diabetogenes, and the cause of type II diabetes. Diabetes 43: 1066-1084

5. Froguel P, Häger N, Vionnet N (1995) Genetics of type 2 diabetes. Current Opinion in Endocrinology and Diabetes 2: 285-289

6. Garvey WT, Maianu L, Huecksteadt TP, Birnbaum MJ, Molina JM, Ciaraldi TP (1991) Pretranslational suppression of a glucose transporter protein causes insulin resistance in adipocytes from patients with non-insulin-dependent-diabetes mellitus and obesity. J Clin Invest 87: 1072-1081

7. Vestergaard H, Lund S, Larsen FS, Bjerrum OJ, Pedersen O (1993) Glycogen synthase and phosphofructokinase protein and mRNA levels in skeletal muscle from insulin-resistant patients with non-insulin-dependent diabetes mellitus. J Clin Invest 91: 2342-2350

8. Vestergaard H, Bjorbaek C, Hansen T, Larsen FS, Granner DK, Pedersen O (1995) Impaired activity and gene expression of hexokinase II in muscle from non-insulin-dependent diabetes mellitus patients. J Clin Invest 96: 2639-2645

9. Brunetti A, Brunetti L, Foti D, Accili D, Goldfine ID (1997) Human diabetes associated with defects in nuclear regulatory proteins for the insulin receptor gene. J Clin Invest 97: 258-262

10. Yamagata K, Oda N, Kaisaki PJ et al. (1996) Mutations in the hepatocyte nuclear factor- $1 \alpha$ gene in maturity-onset diabetes of the young (MODY3). Nature 384: 455-458

11. Yamagata K, Furuta H, Oda N et al. (1996) Mutations in the hepatocyte nuclear factor- $4 \alpha$ gene in maturity-onset diabetes of the young (MODY1). Nature 384: 458-460

12. Arner P, Pollare T, Lithell H, Livingston JN (1987) Defective insulin receptor tyrosine kinase in human skeletal muscle in obesity and type 2 (non-insulin-dependent) diabetes mellitus. Diabetologia 30: $437-440$

13. Zierath JR, Krook A, Wallberg-Henriksson H (1998) Insulin action in skeletal muscle from patients with NIDDM. Mol Cell Biochem 182: $153-160$
14. Björnholm M, Kawano Y, Lehtihet M, Zierath JR (1997) Insulin receptor substrate-1 phosphorylation and phosphatidylinositol 3-kinase activity in skeletal muscle from NIDDM subjects after in vivo insulin stimulation. Diabetes 46: 524-527

15. Goodyear LJ, Giorgino F, Sherman LA, Carey J, Smith RJ, Dohm GL (1995) Insulin receptor phosphorylation, insulin receptor substrate-1 phosphorylation, and phosphatidylinositol 3-kinase activity are decreased in intact skeletal muscle strips from obese subjects. J Clin Invest 95: 2195-2204

16. Rondinone CM, Wang L-M, Lonnroth P, Wesslau C, Pierce JH, Smith U (1997) Insulin receptor substrate (IRS) 1 is reduced and IRS-2 is the main docking protein for phosphatidylinositol 3-kinase in adipocytes from subjects with non-insulin-dependent diabetes mellitus. Proc Natl Acad Sci USA 94: 4171-4175

17. Laville M, Auboeuf D, Khalfallah Y, Vega N, Riou JP, Vidal H (1996) Acute regulation by insulin of phosphatidylinositol-3-kinase, Rad, Glut4 and lipoprotein lipase mRNA levels in human muscle. J Clin Invest 98: 43-49

18. Auboeuf D, Vidal H (1997) The use of the reverse transcriptioncompetitive polymerase chain reaction to investigate the in vivo regulation of gene expression in small tissue samples. Anal Biochem 245: 141-148

19. DeFronzo RA, Tobin JD, Andres R (1979) Glucose clamp technique: a method for quantifying insulin secretion and resistance. Am J Physiol 237: E214-E223

20. Laville M, Rigalleau V, Riou JP, Beylot M (1995) Respective role of plasma non esterified fatty acids oxidation and total lipid oxidation in lipid-induced insulin resistance. Metabolism 44: 639-644

21. Yki-Järvinen H, Koivisto VA (1984) Continuous subcutaneous insulin infusion therapy decreases insulin resistance in type 1 diabetes. J Clin Endocrinol Metab 58: 659-666

22. Vidal H, Auboeuf D, De Vos P et al. (1996) The expression of $o b$ gene is not acutely regulated by insulin and fasting in human abdominal subcutaneous adipose tissue. J Clin Invest 98: 251-255

23. Chomczynski P, Sacchi N (1987) Single step method of RNA isolation by acid guanidinium thiocyanate-phenol-chloroform extraction. Anal Biochem 162: 156-159

24. Zimmermann K, Mannhalter JW (1996) Technical aspect of quantitative competitive PCR. Biothechniques 21: 268-279

25. Krook, A, Roth RA, Jiang XJ, Zierath JR, Wallberd-Henriksson H (1998) Insulin-stimulated Akt kinase activity is reduced in skeletal muscle from NIDDM subjects. Diabetes 47: 1281-1286

26. O'Brien RM, Granner DK (1996) Regulation of gene expression by insulin. Physiol Rev 76: 1109-1161

27. Benecke H, Flier JS, Moller DE (1992) Alternative spliced variants of the insulin receptor protein: Expression in normal and diabetic human tissues. J Clin Invest 89: 2066-2070

28. Cheatham B, Vlahos CJ, Cheatham L, Wang L, Blenis J, Khan RC (1994) Phosphatidylinositol 3-kinase activation is required for insulin stimulation of pp70S6 kinase, DNA synthesis, and glucose transporter translocation. Mol Cell Biol 14: 4902-4911

29. Schalin-Jänti C, Yki-Järvinen H, Koranyi L et al. (1994) Effect of insulin on Glut 4 mRNA and protein concentrations in skeletal muscle of patients with NIDDM and their first-degree relatives. Diabetologia 37: 401-407

30. Baier LJ, Wiedrich C, Hanson RL, Bogardus C (1998) Variant in the regulatory subunit of phosphatidylinositol 3-kinase (p85a): preliminay evidence indicates a potential role of this variant in the acute insulin response and type 2 diabetes in Pima women. Diabetes 47: 973-975

31. Ricort J-M, Tanti J-F, Van Obberghen E, Le Marchand-Brustel Y (1995) Alterations in insulin signalling pathway induced by prolonged insulin treatment of 3T3-L1 adipocytes. Diabetologia 38: $1148-1156$

32. Rice KM, Turnbow MA, Garner CW (1993) Insulin stimulates the degradation of IRS-1 in 3T3-L1 adipocytes. Biochem Biophys Res Commun 190: 961-967

33. Okabayashi Y, Maddux BA, McDoanld AR, Logson CD, Williams JA, Goldfine ID (1989) Mechanism of insulin-induced insulin receptor downregulation. Decrease of receptor biosynthesis and mRNA levels. Diabetes 38: 182-187

34. Vidal H, Auboeuf D, Beylot M, Riou JP (1995) Regulation of insulin receptor mRNA splicing in rat tissues: Effect of fasting, aging and diabetes. Diabetes 44: 1196-1201 